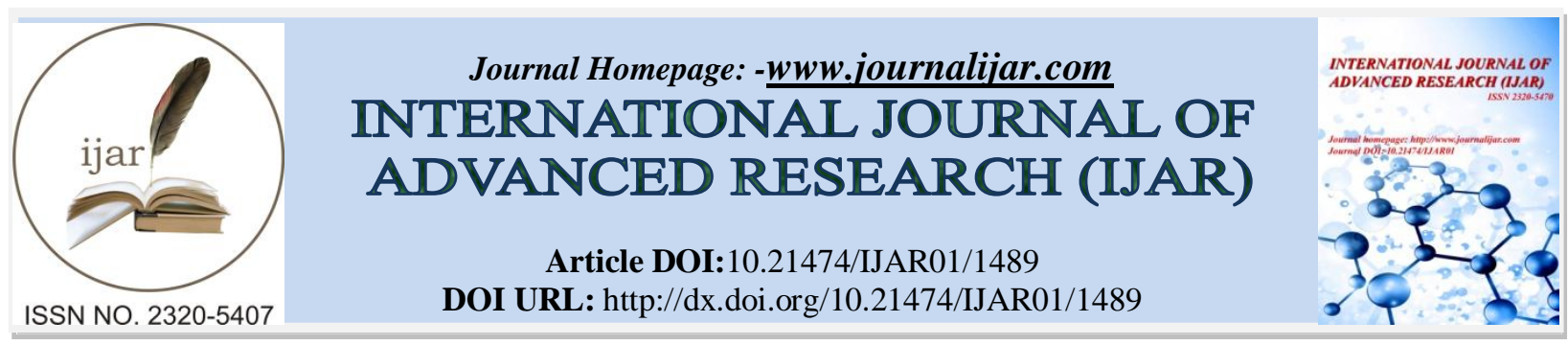

RESEARCH ARTICLE

\title{
QUANTITATIVE STUDIES ON PHYSICO-CHEMICAL PROPERTIES OF GROUND WATER OF KANPUR (UP).
}

Rakesh Kumar Pandey and Harshita Jaiswal.

Assistant Professor, Department of Botany,Shri Jai Narain (PG) College, Lucknow-226001 (UP) India.

\section{Manuscript Info}

Manuscript History

Received: 19 July 2016

Final Accepted: 12 August 2016

Published: September 2016

Key words:-

Ground water, potable, physico-

chemical properties, Total dissolved solid.

\section{Abstract}

Water is elixir of life. Ground water is the waterpresent beneath earth's surface in soil pore spaces and in the fractures of rockformations. Wateristheprincipalneedoflifeonearth, andisanessentialcomponentforallformsoflives, from micro-organism to man. The unplanned urbanization and industrialization has resultedin over use of environment in particular of water resource. It is a known fact that when pure water is polluted its normalfunctioning and properties are affected. The present research paper deals with the study of physico-chemical properties of Potable ground water of Kanpur district in Utter Pradesh (India).

Copy Right, IJAR, 2016,. All rights reserved.

\section{Introduction:-}

In recent years, an increasing threat to ground water quality due to human activities has become of great importance. The adverse effects on ground water quality are the results of man's activity at ground surface, unintentionally by agriculture, domestic and industrial effluents, unexpectedly by sub-surface or surface disposal of sewage and industrial wastes. The quality of ground water is of great importance in determining the suitability of particular ground water for a certain use (public water supply, irrigation, industrial applications, power generation etc.). The quality of ground water is the resultant of all the processes and reactions that have acted on the water from the moment it condensed in the atmosphere to the time it is discharged by a well. Therefore, the quality of ground water varies from place to place, with the depth of water level, and from season to season and is primarily governed by the extent and composition of dissolved solids present in it. A vast majority of ground water quality problems are caused by contamination, over-exploitation, or combination of the two. Most ground water quality problems are difficult to detect and hard to resolve. The solutions are usually very expensive, time consuming and not always effective. Ground water quality is slowly but surely declining everywhere. Ground water pollution is intrinsically difficult to detect, since problem may well be concealed below the surface and monitoring is costly, time consuming and somewhat hit-or-miss by nature. The wide range of contamination sources is one of the many factors contributing to the complexity of groundwater assessment. It is important to know the geochemistry of the chemical-soilgroundwater interactions in order to assess the fate and impact of pollutant discharged on to the ground. Pollutants move through several different hydrologic zones as they migrate through the soil to the water level. The serious implications of this problem necessitate an integrated approach in explicit terms to undertake ground water pollution monitoring and abatement programs. A major problem in urbanized areas is the collection and disposal of domestic wastes. Because a large volume of sewage is generated in a small area, the waste cannot be adequately disposed off by conventional septic tanks and cesspools. Therefore, special disposal sites are being used to collect and dispose such wastes in densely populated areas (Patilet al.2012). 


\section{Material and Methods:-}

It is very essential and important to test the water before it is used for drinking, domestic, agricultural or industrial purpose. Water must be tested with different physico-chemical parameters. Selection of parameters for testing of water is solely depends upon for what purpose we going to use that water and what extent we need its quality and purity. Water does content different types of floating, dissolved, suspended and microbiological as well as bacteriological impurities. Some physical test should be performed for testing of its physical appearance such as temperature, color, odour, $\mathrm{pH}$, turbidity, TDS etc., while chemical tests should be perform for its alkalinity, hardness and other characters. For obtaining more and more quality and purity water, it should be tested for its trace metal, heavy metal contents and organic i.e. pesticide residue. It is obvious that drinking water should pass these entire tests and it should content required amount of mineral level. Only in the developed countries all these criteria's are strictly monitored. Due to very low concentration of heavy metal and organic pesticide impurities present in water it need highly sophisticated analytical instruments and well trained manpower.

Water samples were collected from submersible pump at Bahlolpur village, near Mandhana town of Kanpur (Uttar Pradesh) in December-2012. Samples were packed in 1 liter PET bottles and capped. 6 liter samples were sent to Gujarat Test House (Health Care Division), L-1, 2, 13 \& 14 "Samrudhi", opposite C. U. Shah College, Ashram Road Ahmedabad- 380014, Gujarat for testing of all physico-chemical parameter as per IS:10500- 1991.

\section{Results and Discussion:-}

The detail of physico chemical properties of ground water of Mandhana, Kanpur along with maximum desirable limit and maximum permissible limit in the absence of alternative sources as per Bureau of Indian Standard IS:10500 -1991 is given in table-1.

Table 1:-Physico-chemical properties of ground water of Kanpur.

\begin{tabular}{|c|c|c|c|c|c|}
\hline $\begin{array}{c}\text { Serial } \\
\text { No. }\end{array}$ & Tested Parameter with unit & $\begin{array}{c}\text { Maximum } \\
\text { Desirable limit }\end{array}$ & $\begin{array}{l}\text { Maximum Permissible limit in the } \\
\text { absence of alternate source }\end{array}$ & Result & Test method used \\
\hline 01 & Colour, Hazen unit & 5 & 25 & 1.0 & IS:3025 (P-4) \\
\hline 02 & Odour & Agreeable & Agreeable & Agreeable & IS:3025 (P-5) \\
\hline 03 & Taste & Agreeable & Agreeable & Agreeable & IS:3025(P-7,8) \\
\hline 04 & Turbidity, NTU & 5 & 10 & 0.1 & IS:3025 (P-10) \\
\hline 05 & $\mathrm{pH}$ & 6.5 to 8.5 & No relaxation & 7.94 & IS:3025 (P-11) \\
\hline 06 & Chloride as $\mathrm{Cl}, \mathrm{mg} / \mathrm{l}$ & 250 & 1000 & 65.9 & IS:3025 (P-32) \\
\hline 07 & Calcium, mg/l & 75 & 200 & 78.6 & IS:3025 (P-40) \\
\hline 08 & Magnesium, mg/l & 30 & 100 & 0.9 & IS:3025 (P-46) \\
\hline 09 & Total Hardness mg/l & 300 & 600 & 276 & IS:3025 (P-21) \\
\hline 10 & Total Dissolved Solid, mg/l & 500 & 2000 & 359.4 & IS:3025 (P-16) \\
\hline 11 & Residual free Chlorine, $\mathrm{mg} / \mathrm{l}$ & 0.20 & 0.20 & Absent & IS:3025 (P-26) \\
\hline 12 & Alkalinity, mg/l & 200 & 600 & 95 & IS:3025 (P-23) \\
\hline 13 & Sulphate as $\mathrm{SO}_{4}, \mathrm{mg} / \mathrm{l}$ & 200 & 400 & 13.6 & IS:3025 (P-24) \\
\hline 14 & Fluoride as $\mathrm{F}, \mathrm{mg} / \mathrm{l}$ & 1.0 & 1.5 & 0.9 & 23 of IS:3025 \\
\hline 15 & Aluminum as $\mathrm{Al}, \mathrm{mg} / \mathrm{l}$ & 0.03 & 0.2 & 0.004 & IS:3025 (P-55) \\
\hline 16 & Nitrate as $\mathrm{NO}_{3}, \mathrm{mg} / \mathrm{l}$ & 45 & No relaxation & 12.0 & IS:3025 (P-34) \\
\hline 17 & Boron as $\mathrm{B}, \mathrm{mg} / \mathrm{l}$ & 1.00 & 5.00 & 0.80 & $\begin{array}{lll}\text { Annex } & \mathrm{H} & \text { of } \\
\text { IS:13428 } & & \end{array}$ \\
\hline 18 & Copper as $\mathrm{Cu}, \mathrm{mg} / \mathrm{l}$ & 0.05 & 1.5 & 0.002 & IS:3025 (P-42) \\
\hline 19 & Iron as $\mathrm{Fe}, \mathrm{mg} / \mathrm{l}$ & 0.30 & 1.0 & 0.05 & IS:3025 (P-53) \\
\hline 20 & Manganese as Mn, mg/l & 0.1 & 0.3 & 0.01 & IS:3025 (P-35) \\
\hline 21 & Mercury as $\mathrm{Hg}, \mathrm{mg} / \mathrm{l}$ & 0.001 & No relaxation & 0.0004 & IS:3025 (P-48) \\
\hline 22 & Cadmium as $\mathrm{Cd}, \mathrm{mg} / \mathrm{l}$ & 0.01 & No relaxation & 0.003 & IS:3025 (P-41) \\
\hline 23 & Arsenic as As, mg/l & 0.01 & No relaxation & Not detected & IS:3025 (P-37) \\
\hline 24 & Cyanide as $\mathrm{CN}, \mathrm{mg} / \mathrm{l}$ & 0.05 & No relaxation & Absent & IS:3025 (P-27) \\
\hline 25 & Lead as $\mathrm{Pb}, \mathrm{mg} / \mathrm{l}$ & 0.05 & No relaxation & Not detected & IS:3025 (P-47) \\
\hline 26 & Chromium as $\mathrm{Cr}, \mathrm{mg} / \mathrm{l}$ & 0.05 & No relaxation & Not detected & IS:3025 (P-52) \\
\hline 27 & Zinc as $\mathrm{Zn}, \mathrm{mg} / \mathrm{l}$ & 5.00 & 15 & 0.2 & IS:3025 (P-49) \\
\hline
\end{tabular}




\begin{tabular}{|l|l|c|c|c|l|}
\hline 28 & Selenium as Se, $\mathrm{mg} / \mathrm{l}$ & 0.01 & No relaxation & Not detected & IS:3025 (P-56) \\
\hline 29 & Phenolic Compounds & 0.001 & 0.002 & Absent & IS:3025 (P-43) \\
\hline 30 & Mineral oils & Absent & Absent & Absent & IS:3025 (P-39) \\
\hline
\end{tabular}

A lot of works have been carried out by different investigators to study the physico-chemical properties of potable water as well as polluted water in different parts of India.Physico-chemical properties of Ganga River have already been assessed by the author (Jaiswal, H. et al. 2013 \& 2015a and b). PawarAnushaet al. (2006) studied the bore well and dug well water samples from a highly polluted industrial area - Nacharam. Sample were collected and analyzed for physico-chemical parameters by adopting the standard methods for examination of water and waste water. The analyzed samples obtained a high values, compared with drinking water standards. The studies on physicochemical and microbiological parameters of automobile wastewater in Nammakkal, Tamil Nadu, India indicated that the values for physico-chemical parameters were on the higher side of permissible limits of BIS (Poonkothai and Parvatham2005). On the same site microbiological studies revealed the presence of bacteria at high concentration and these organisms' serves as indicators for pollutants.Pollution in Salim Ali lake Aurangabad was studied and high fluctuations in the physico-chemical parameters were observed that indicate the intensity of pollution (Rokade and Ganeshwade 2005). The groundwater of Bijjoli area of Jhansi district was analyzed for various physico-chemical parameters (Kumar and Kumar 2012). They find that most of the physico-chemical parameters like alkalinity, turbidity, D.O, total hardness, nitrate, fluoride, iron and chloride are well within limit. Although all the parameters are within maximum acceptable limit but the water is slightly acidic. An extensive quantitative study on the ground water of the Agra indicate that the underground potable water of Agra is though fit for drinking purpose yet it need few treatment to minimize some contaminations especially total hardness and fluoride which are reported to be on higher level (Pandey 1916).

\section{Conclusion:-}

All the results of physical and chemical parameters were analyzed according to IS:10500-1991 Although all the parameters are within maximum acceptable limit but the water is slightly alkaline. From the result of above experiments author conclude that the ground potable water of Kanpur is though fit for drinking purpose yet it need few treatment to minimize some contaminations especially Boron, Iron and fluoride which are reported to be on higher level.

\section{Acknowledgements:-}

Thanks are due to Prof. S. D. Sharma Principal and Dr. A. B. Mishra, Head of the department, Botany, Shri jai Narain PG College, Lucknow for providing facilities and encouragements.

\section{References:-}

1. BIS (1991): Specifications for Drinking Water, IS:10500:1991, Bureau of Indian Standards, New Delhi.

2. Jaiswal, H., Tewari, V., and Pandey, R. K. (2012):Monthly variations in physico-chemical characteristics of river Ganga at Kanpur (UP) India. Flora and Fauna, 18(1):51-53.

3. Jaiswal, H., Tewari, V., and Pandey, R. K. (2015a):Sediment analysis of the upstream river Gangaes in Kanpur (U.P.). Global Journal of Bio-science and Biotechnology,4(1): 99-102.

4. Jaiswal, H., Tewari, V., Pandey, R. and Kumar A. (2015b):Water quality survey of Ganga barrage ghat in Kanpur Ganga river. Vigyan Shakti, 1 (2):42-45.

5. Kumar, M. and Kumar, R. (2012): Assessment of physiochemical properties of ground water in granite mining areas of Jhansi UP. Int. J. of Engg. Res. and Tech.,1(7):1-9.

6. Pandey Rakesh Kumar 2016: Quantitative Studies on Physico- chemical Properties of Ground water of Agra. World Journal of Biology and Medical Sciences, 3 (1): 132-136.

7. Patil, P.N., Sawant, D.V., and Deshmukh, R.N. (2012):Physico-chemical parameters for testing of water- A review. Int. J. of Environ. Sci., 3(3): 1194-1206.

8. Pawar, Anusha, C., Nair, Jithender, Kumar, Jadhav, Naresh, Vasundhara, Devi, V., Pawar, Smita, C., 2006: Physico-chemical study of ground work samples from NacharamIndustrial area, Hyderabad, Andhra Pradesh. Journal of Aquatic Biology, 21(1): 118-120.

9. Poonkothai, M. and Parvatham, R., (2005): Bio-physico and chemical assessment of automobile wastewater. Journal of Industrial Pollution Control, 21 (2): 377-380.

10. Rokade, P. B. and Ganeshwade, R. M., (2005): Impact of pollution on water quality of Salim Ali Lake at Aurangabad, Uttar Pradesh. Journal of Zoology, 25(2): 219-220. 